\title{
DEVELOPMENT OF POTENTIAL ENTERPRENEURSHIP TRANSPARENT HERBAL SOAP IN INTEGRATED PUBLIC SPACE FOR FRIENDLY CHILDREN KALIDERES WEST JAKARTA
}

\author{
Sawarni Hasibuan \\ Master of Industrial Engineering Program, Mercu Buana University, Jakarta \\ sawarni02@gmail.com
}

\begin{abstract}
As one program of Jakarta province government, integrated public space for friendly children in Kalideres West Jakarta begins with the social mapping activity to identify the need for indoor room and outdoor room in RPTRA Kalideres. One of indoor room built in RPTRA Kalideres is PKK Mart. PKK mart is built as storefront to put and promote innovative products and creativity of Kalideres citizen contributing to improve the familiy economics. One of excellent program in RPTRA Kalideres is cultivation of various herbal plants in the home garden. The herbal products are then dried in the form of Simplisia, packed simply and marketed in PKK Mart. Alternative product diversification of other herbal products are dried flour, herbal tea, herbal drink and herbal soap. The problem is that management of RPTRA Kalideres and PKK housewives have not owned the knowledge about business development of herbal plants based. The purpose of this community dedication is to develop the products of herbal plants based transparent soap. Training given consists of knowledge and skills to produce transparent herbal soap, packaging innovation, analysis of production cost and marketing innovation by using social media. The activity lasted for four months involving 35 candidates of enterprenour in region Kalideres. Result of evaluation showed that interest of the participants is quite high to develop enreprenourship including this transparent herbal soap. Design to develop enterprenourship of transparent herbal soap is integrated from raw products to finished products. They also increase innovation for developing products among the participants. The next step is finding partnership for the success of continuity for excellent program RPTRA Kalideres West Jakarta.
\end{abstract}

Keywords: Family economics, PKK Mart, RPTRA Kalideres, transparent herbal soap.

\section{INTRODUCTION}

Region Kalideres West Jakarta is one region in jakarta province given the trust to manage Integrated Public Space for Friendly Children (RPTRA). RPTRA is one of province government program. Jakarta province in the framework to provide Integrated Public Space for Friendly Children in all regions in DKI Jakarta has completed with physical facilities. The function is as the facility to give service and activity especially for children and the citizen so that RPTRA becomes place for raising and growing children , place for ground water etc.. Beides, RPTRA can also become the palce for learning, training, developing and reference for various activity groups (POKTAN). The program and activities of RPTRA are integrated with 10 basic programs of PKK ( Program for Family Prosperity) which principally is the basic needs of humanbeings as well as children including (1) undrestanding and implementing Pancasila (2) working together (3)Food (4) Clothes (5) Housing and Household management (6) Education and Skills (7) Health (8) Developing Cooperative life (9) Preserving environment (10) Planning healthy life

Since officially opened by governor of DKI Jakarta on May 3, 2016, RPTRA Kalidrees Jakarta has run various program indoor as well as outdoor. Some excellent program by moving team of PKK and karang Taruna region Kalideres developed before are integrated with RPTRA Kalideres. The existence of indoor multifunction room enables to conduct various activities like training and educating skills. So far, skill activities are done by housewives of PKK dominated by the business of food products and hadicrafts. Products of food like semprong cookies, Cilok, Fruit sweets and cocktail are produced at home by housewives in region Kalideres. The same thing with handicraft is only dominated 
by some housewives. Food products and handicrafts are marketed in the region of kalideres. RPTRA also facilitates the marketing products by housewives of PKK and Karang taruna in PKK Mart.

Besides food and handicraft, PKK Mart RPTRA also need to develop excellent products which have basic potentials for prospective market. Among the products which have interesting prospect to be developed is transparent herbal soap. The vacancy for business of transparent herbal soap has never been done by housewives of PKK although the prospect is very good. The business of transparent herbal soap in RPTRA Kalideres can become the alternative for excellent products in RPTRA Kalideres. The production can be done by housewives of PKK and Karang Taruna because the production process is not difficult to do. Consideration to choose transparent herbal soap is because most of herbal material like Sereh leaf, Lengkoas, Kunyit etc has been cultivated in the ground of RPTRA Kalideres Products of herbal soap can become the icon of RPTRA Kalideres in the future.

\section{LITERATURE REVIEW}

\section{Transparent Herbal Soap}

Soap is defined as products which are produced from reaction of saponification proces and netralisation of lipid acid, oil, candle, and resin with certain organic base like ammonia or amina (derivation of ammonia like trietanol amina) and an organic base. Chemical reaction of safonification process can be seen in Figure 1.

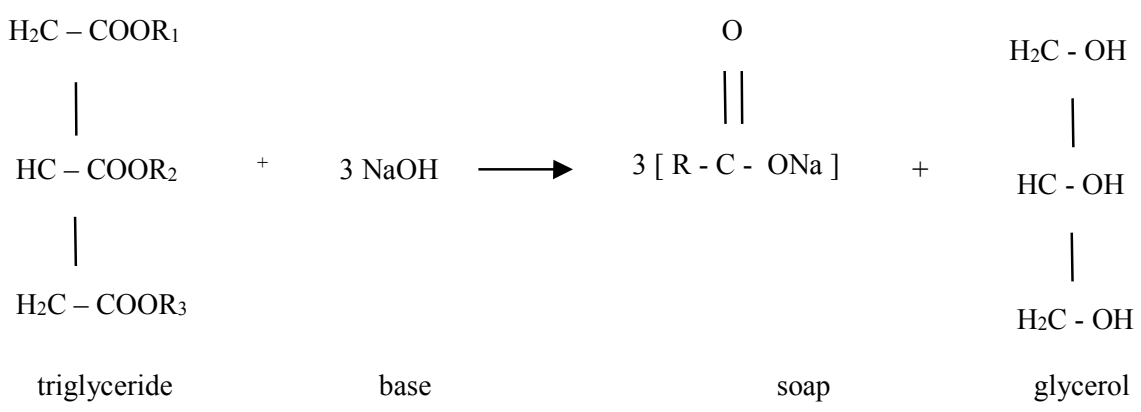

Figure 1. Chemical reaction of triglyceride saponification process (Mitsui 1997).

Characteristics of a soap is very influenced by characteristics of oil used. Each oil also has type of dominant fat acid. These fat acids later will determined characteristics of soap produced. Methods of producing transparent herbal soap can be done by 3 ways those are cold process, hot process, and transparent soap/gliserin soap process. Technique of making soap by cold process and cold process is commonly the same in using the substance and mixing process. The difference is in the curing process. In the cold process needs curing process for $4-6$ weeks while in hot process the soap can be directly used fresh from the oven.

Transparent soap is the soap having high transparancy which can reflect its light dispersion, so that the object outside the soap can be clearly seen (Cavith,1997). Structure of the transparent soap can be formed by adding transparent agent like gliserin, sucrosa, and alcohol in formulation of making transparent soap. Adding gliserin in the process of making transparent soap has purpose to form physical appearance of soap with the characteristics final form of appearance transparent color, shining and produce softer foam in the skin.

The quality of soap products is influenced by many factors, on ecomposition of different trigliserida influences level of hardness and soap solution to water. Kind of fat acid is really influencing to characteristics of soap like laurat acid $(\mathrm{C} 12: 0)$ and miristat acid which can give characteristics of hardening, cleaning, and giving soft foam. Differnt with linoleat acid (C18:2) and oleat acid (18:1) which gives softening characteristic to the soap. While palmitat acid, linoleat, and stearat acid (C18:0) gives characteristics of hardening and foam stabilizing. In Table 1 is shown characteristics of soap produced from different fat acid 
Tabel 1 Influence of fat acid to soap characteristics (Cavit, 1997)

\begin{tabular}{|c|c|c|c|c|c|c|}
\hline \multicolumn{7}{|c|}{ Fat Acid type } \\
\hline Laurat & Linoleat & Miristat & Oleat & Palmitat & Risinoleat & Stearat \\
\hline $\begin{array}{l}\text { Hardening } \\
\text { Cleaning } \\
\text { Soft foam }\end{array}$ & $\begin{array}{l}\text { Moisturiz- } \\
\text { ing }\end{array}$ & $\begin{array}{l}\text { Hardening } \\
\text { Cleaning } \\
\text { Soft foam }\end{array}$ & Moisturizing & $\begin{array}{l}\text { Hardening } \\
\text { Stabile } \\
\text { foam }\end{array}$ & $\begin{array}{l}\text { Soft and } \\
\text { stabile foam } \\
\text { Moisturizing }\end{array}$ & $\begin{array}{l}\text { Hardening } \\
\text { Stabile } \\
\text { foam }\end{array}$ \\
\hline
\end{tabular}

Basically, substance for making soap consists of basic substance and additional substance. Basic substance is solution or basic place for other substance so commonly need bigger volume than other material. Additive substance is the substance function to give certain effect needed by the consumer (Wasitaatmaja,1997). Things to pay attention in formulating soap among others are good characteristics of foaming. Not irritating to eyes, mucosa membrane, having optimal cleaning and not giving damaging and having fresh and interesting fragrance (Fahmitasari, 2004)

\section{Herbal Soap}

Now there are many people like herbal products because herbal substance is safe and has more advantages because they are natural. Herbal natural product .can also be utilised for soap product. Where the soap is included in the basic needs and are used everyday. Herbal soap is suitable to use for all kinds of skin.

Advantages of herbal soap can be seen from many aspects for example from the natural fragrance. Consumers usually try to smell the fragrance of the soap. Consumers choose the soap because of the natural fragrance like flower extract, honey and other natural substance. Natural substance has smaller risk of side effect compared to chemical substance. Not all people have the same sensitivity, so many people are very selective in deciding kind of soap, if not the skin can be itching and red spotted. Herbal soap originated from natural substance ofcourse will not cause irritation and other skin diseases.

Herbal soap now has been circulating like milk soap, olive soap, ginseng, aloe vera, noni, papaya, sereh, ginger, curcuma, tomato, avocado, bengkuang etc. With certain advantages and function as beauty soap, care soap and curing soap. Production of naturl herbal soap can be done at home. Only by nusing instrument at home, kitchen tools, it can be made many kinds of herbal soap which has the same quality with soap produced by factory. Advantages of herbal /natural soap compared to other soap in the market is that most of the substance is herbal except lye and do not contain SLS (Sodium Lauret Sulfat) .

Lye is chemical substance we must be careful to use because if the titration is over can be dangerous to human body and the environment, but accuracy in the composition can form safe soap to use fro cleaning body from all kinds of dirts.

\section{Quality of transparent soap}

Until now there is no SNI for transparent soap. Standard of transparent herbal soap adopts the standard of glycerin soap given bu SASO in the year 2008 like shown in Table 2.

Tabel 2 Standard of glycerin, transparent soap, and non transparent according to SASO (2008)

\begin{tabular}{lc}
\hline Parameter & Proportion \\
\hline Proportion of glycerin & $\min 5 \%$ \\
Proportion of water and steaming material & $\min 17 \%$ \\
Total proportion of fat & $\min 65 \%$ \\
Proportion of unsolved material in the water & $\max 5 \%$ \\
Proportion of unsolved materail in the alcohol & $\operatorname{max~} 2 \%$ \\
Total proportion of free alkali counted as NAOH & $\operatorname{max~} 1 \%$ \\
Proportion of free acids & $\max 0.2 \%$ \\
Proportion of unsaponification lipid acid & $\max 2 \%$ \\
\hline
\end{tabular}




\section{METHOD}

Herbal soap is combination between beauty soap and herbal soap. The herbal advantage contains in this herbal soap makes the price more expensive than ordinary soap. Many herbal plants are taken the extract to be applied in the formulae of soap i.e. ginger, turmeric, lemongrass, and so on.

The making transparent herbal soap process is relatively easy. The first step is to choose the herbal plants that having advantages to the skin and having nice fragrance. Additive substance is herb oil and other substance like goat milk and cow milk can be alternative to make herbal soap. Commonly the steps to make transparent herbal soap is as follows:

1) Prepare the tools and ingredients needed to make transparent herbal soap.

a. Smooth the herbals ingredients that will be added to the soap formula.

b. Heats $60-80 \mathrm{ml}$ of water and heats the herbal ingredients for 15 minutes until half of the water steaming and the rest is $30-60 \mathrm{ml}$

2) Prepare lye solution of $35 \%$ concentration.

3) Preparing necessary ingredients such as vegetable oils (palm oil, coconut oil), essential oils, fatty acids (stearate acid), glycerol, granulated sugar, citric acid, natural dyes, fragrance, DEA, and propylene glycol.

4) Heat stearic acid until liquid and mix with vegetable oil until clear then add $\mathrm{NaOH}$ solution (lye) to form a soap solution at $60^{\circ} \mathrm{C}$.

5) Next mix the alcohol solution into a solution of soap and sugar, DEA, propylene glycol, and citric acid; stirring continues until homogeneous. The last is adding herbal solutions, natural dyes, and fragrance.

6) After perfectly mixing the soap solution can be poured into the soap mold according to the desired design needed.

7) Soap is allowed to stand for 30 minutes until the surface of the soap hardens. To reduce surface tension can be sprayed with an alcohol solution.

8) Keep the molding of soap in the freezer to make the soap harden faster, but this step is optional

9) Curing is done for 24 hours.

10) Soap is removed from the mold and can be packed using primary/secondary packaging.
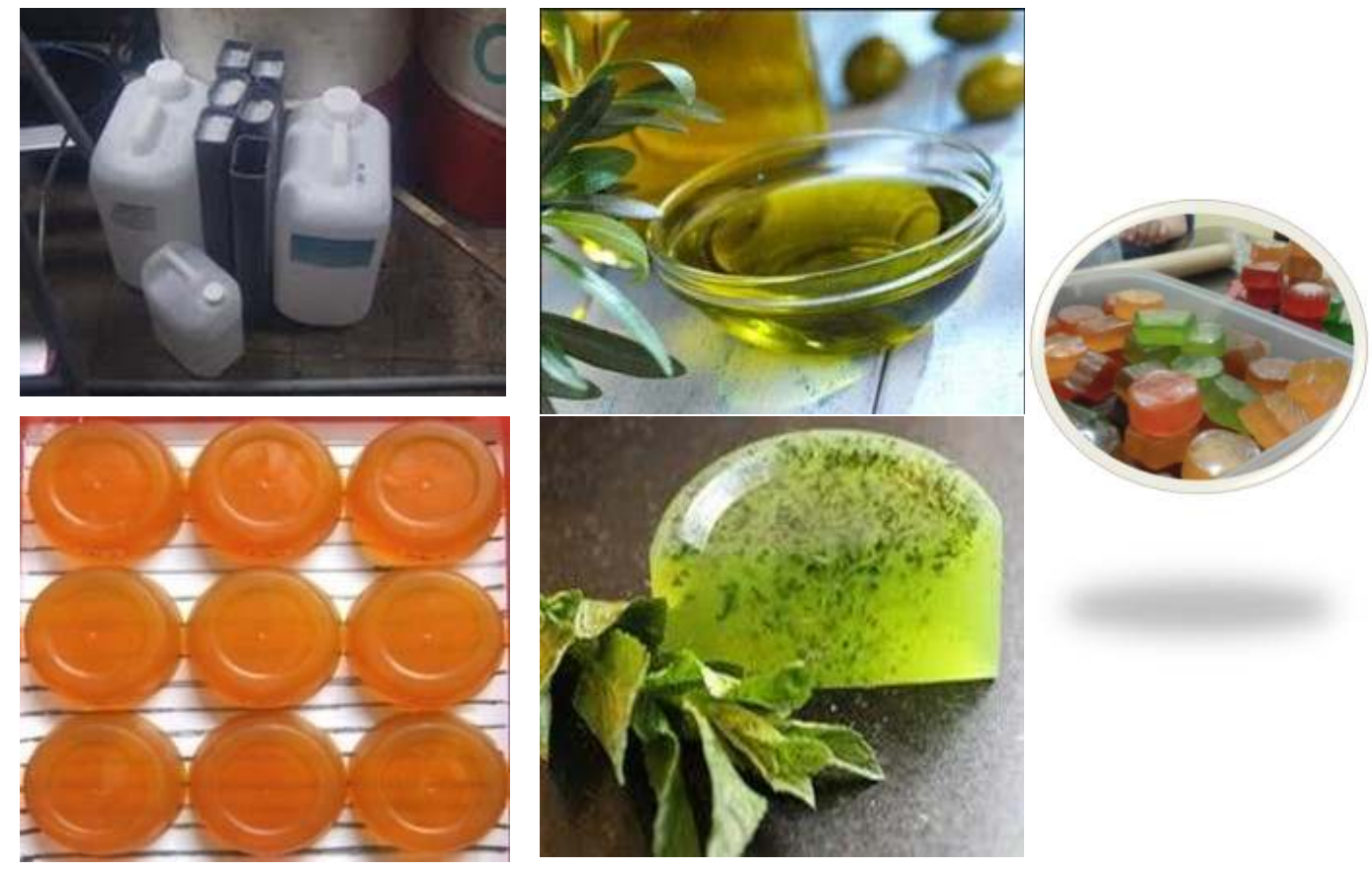

Figure 2. Practice of producing transparent herbal soap 


\section{RESULT AND DISCUSSION}

\section{Strength of transparent herbal soap}

1) Almost all materials are herbal except lye

2) Not containing SLS (Sodium Laureth Sulfate)

3) The solving material is VCO coconut and olive oil which is believed to have advantages for beauty and skin health

4) Use minimum perfume which is easily removed by water so that not causing danger to the skin

5) Not using coloring and other chemical material execpt lye and perfume

6) Guaranted halal. Not using lard. Lard is usually used as basic material to make soap by non moslem producer

7) Additive herbal (papaya, avocado, bengkoang) is added as juice not extract until more than $30 \%$.

\section{Evaluation of Training Activity}

Training to make transparent herbal soap is conducted in the building of RPTRA Kalideres West Jakarta. This training to make transparent herbal soap is done by community service centre Universitas Mercu Buana in the framework of effectivity and sustainability of RPTRA Kalideres program. After finished training of making transparent herbal soap in RPTRA Kalideres West Jakarta is done evaluation about adavantages and participants' understanding of the material given and the conduction of training activity. The result showed that all participants (100 percent) have not gotten the training of transparent herbal soap before, so the training material given is considered very important by 100 percent participant.

From the aspect of understanding, almost all participants (90 percent) say that they could understand the material of training making transparent herbal soap. This indicates that simple expalanation plus practical demonstration was easily understood by the training participants. From the aspect of conducting training, participants said that it is satisfying enough as well as for the consumption. Only for the aspect of delivering material (15 percent) participnts said that the time is not long enough to make the discussion end perfectly. This weakness is because of the time for production training was only one day. The participants also hoped that there is a follow up of training activity to make transparent herbal soap.
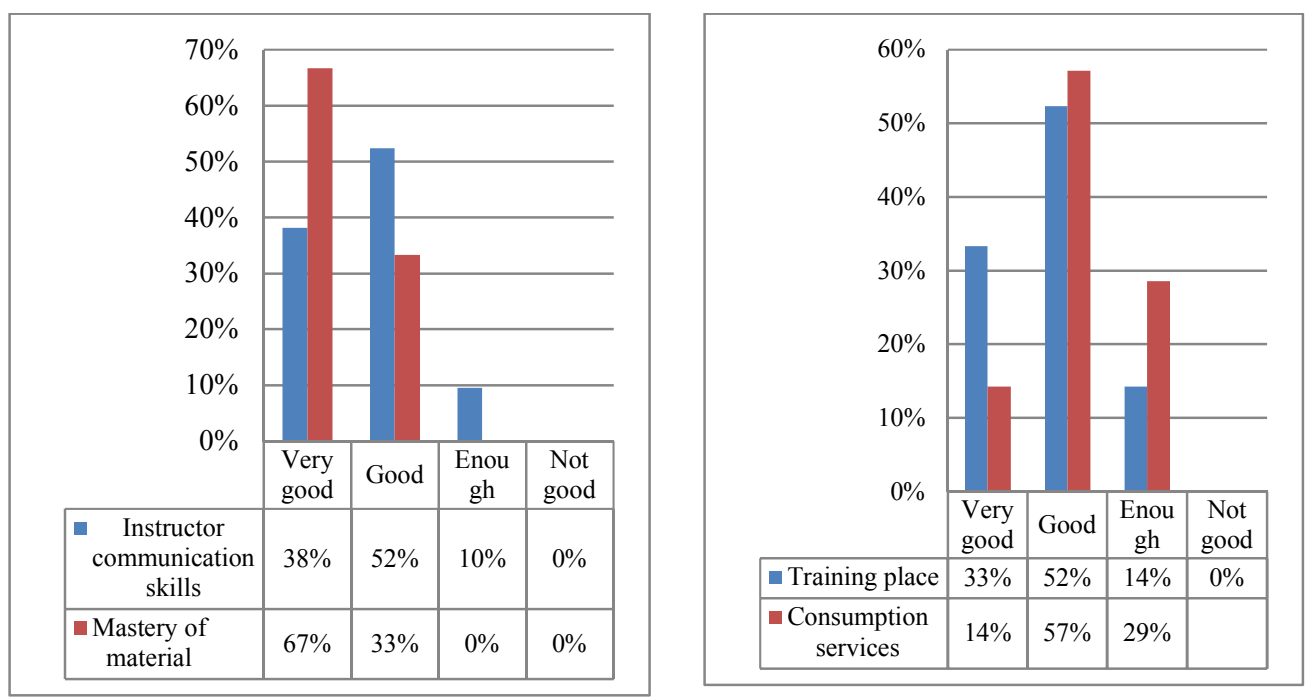


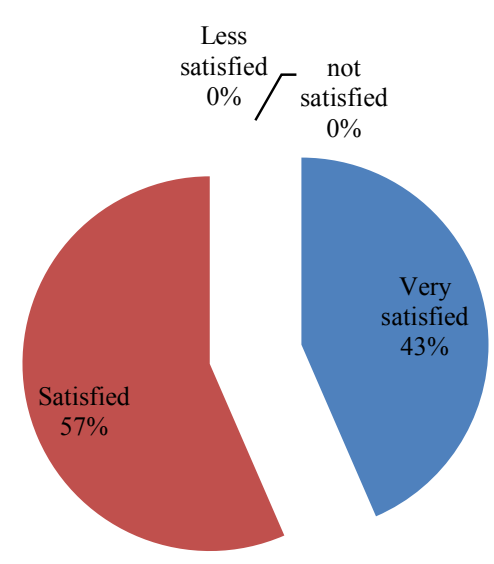

Assessment of Instructor

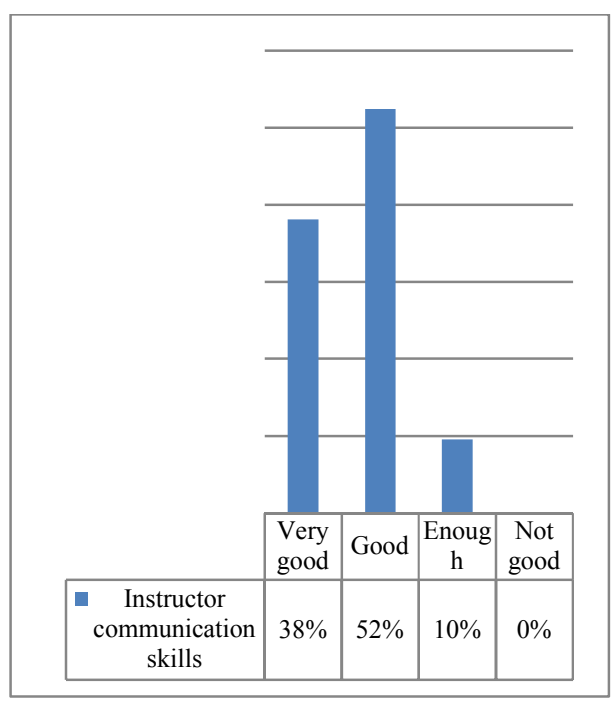

Figure 3. Evaluation results of conducting activity of making transparent herbal soap

\section{CONCLUSION}

Products of soap have developed to be primary needs in the society, utilised by all level of society everyday. Industries of soapcompete to create products which is inno vative and useful, varietive in the form, color and fragrance. Now product of herbal based soap is still circulating limitedly in the market. Most soap still use sinthetical active substance and has negative effect to human skin, because it has potential to cause irritation to consumer's sensitive skin. Example of dangerous synthetical active substance for human skin and are exposed much now is diethanolamine (DEA) and Sodium Lauryl Sulfate (SLS), and triclosan exist in almost all kinds of health soap circulating in in the market. Based on the research, if triclosan is acumulated in the fat of human body, it has potentioal to cause tirroid disfunction. Therefore, now many producers of soap are finding natural substance to be made subtitute of active substance for producing health soap. The purpose is to eliminate synthetical substance, the coloring, perfume, whitening, antibacterial etc.

Potential of herbal plants cultivated in RPTRA Kalideres West Jakarta can be utilised actively as active substance to make transparent herbal soap. Potential market for transparent soap products is prospective enough especially in city envoirontment because of its interesting characteristics and herbal advantages, it will give plus value to the soap products. Unfortunately, now housewives of PKK region Kalideres has not owned knowledge and skills in producing transparent herbal soap with quality requirement of transparent soap.

Based on the condition above, it is necessary to give training of producing transparent herbal soap to increase knowledge of RPTRA management, housewives of PKK and Karang Taruna in region Kalideres which can become icon of RPTRA region Kalideres in the future. So there is integration between activity of cultivating herbal palnts and producing transparent soap with herbal advantages. Besides knowledge and skills in production process, training participants also need to be compeleted with knowledge of product packaging innovation, analysis of production cost and marketing innovation.

\section{REFERENCES}

Evans, D. C. (1937). Experimental soap making. J. Chem. Educ, 14(11), 534.

Hasibuan, S., Sahirman, S., \& Ma'ruf, A. (2014). The Quality of Transparent Soap from Farmer's Crude Calophyllum Seed Oil. International Journal on Advanced Science, Engineering and Information Technology, 4(5), 349-353. 
Panda, H. (2011). Herbal Soaps \& Detergents Handbook. NIIR PROJECT CONSULTANCY SERVICES.

Ruckmani, K., Krishnamoorthy, R., Samuel, S., \& Kumari, H. L. J. Formulation of Herbal Bath Soap from Vitex negundo Leaf Extract. Journal of Chemical and Pharmaceutical Sciences ISSN, 974, 2115.

Thomssen, E. G. (1922). Soap-making manual: a practical handbook on the raw materials, their manipulation, analysis and control in the modern soap plant. Van Nostrand.

Thomssen, E. G. (1922). Soap-Making Manual. Analysis, 151, 154.

http://www.pharmacy.mahidol.ac.th/newspdf/specialproject/2547-21.pdf

http://www.tbtvn.org/VBLienQuanTBT/QCKT\%20nuoc\%20ngoai/SAU73(english).pdf

http://jtk.unsri.ac.id/index.php/jtk/article/viewFile/99/98

http://bplhd.jakarta.go.id/SLHD2016/Docs/pdf/Buku\%20II/UP-2B(T).pdf

http://eprints.undip.ac.id/3662/1/makalah_seminar_soda_Q_pdf.pdf

http://lppm.ikipmataram.ac.id/wp-content/uploads/2015/04/Baiq-Risni-Maripa-Pengaruh-Konsentrasi$\mathrm{NaOH}$-terhadap-Kualitas-Sabun-Padat-dari-Minyak-Kelapa-Pend-Kimia.pdf

http://download.portalgaruda.org/article.php?article=105940\&val=2286

http://download.portalgaruda.org/article.php?article=15296\&val=1014file://C:/Users/ASPIRE\%20V3 /Downloads/125-460-1-PB\%20(1).pdf

http://eprints.ums.ac.id/24210/12/10._NASKAH_PUBLIKASI.pdf

http://www.ejournal.stikesmucis.ac.id/file.php?file=preview_mahasiswa\&id=974\&cd=0b2173ff6ad6a 6fb09c95f6d50001df6\&name=13DF277018.pdf

http://ejournal.uhamka.ac.id/files/disk1/4/universitas\%20muhammadiyah\%20prof.dr.hamka-susisusant-158-1-jurnals-4.pdf

http://jurnal.pnl.ac.id/wp-content/plugins/Flutter/files_flutter/1429519026AplikasiMinyakNilam2.pdf

http://eprints.ums.ac.id/24220/11/NASKAH_PUBLIKASI.pdf

http://digilib.its.ac.id/public/ITS-NonDegree-16902-Presentation-2296099.pdf 